\title{
Storage protocol of dental pulp cells from human exfoliated deciduous teeth
}

\author{
Protocolo de armazenamento de células pulpares de dentes decíduos humanos
}

Natalino LOURENÇO NETO ${ }^{1}$, Letícia Florindo PEREIRA², Nádia Carolina Teixeira MARQUES ${ }^{1}$, Mariel Tavares Oliveira PRADO ${ }^{1}$, Luciana Lourenço Ribeiro VITOR ${ }^{1}$, Cintia Kazuko TOKUHARA ${ }^{3}$, Rodrigo Cardoso OLIVEIRA ${ }^{3}$, Maria Aparecida Andrade Moreira MACHADO $^{1}$, Thais Marchini OLIVEIRA ${ }^{1}$

1 - Department of Pediatric Dentistry, Orthodontics and Public Health - Bauru School of Dentistry - University of São Paulo - Bauru - São Paulo - Brazil.

2 - Bauru School of Dentistry - University of São Paulo - Bauru - São Paulo - Brazil.

3 - Department of Biological Sciences - Bauru School of Dentistry - University of São Paulo - Bauru - São Paulo - Brazil.

\begin{abstract}
Objective: This study aimed to isolate the cells from the dental pulp tissue of human primary teeth, study the capacity of proliferation, characterize the cells and standardize the technique of culture and expansion to create a cell banking. Material and Methods: Primary teeth with no caries and orthodontic reasons were extracted for pulp tissue obtainment. The cells were extracted from the pulp cells, isolated and cultured under ideal conditions until full expansion. Results: After consecutive passages, the cultured cells were characterized using immunofluorescence technique and frozen between the $2^{\text {nd }}$ and $6^{\text {th }}$ passage, thus creating a biorepository of dental pulp cells from human primary teeth. Conclusion: The creation of a cell banking from dental pulp cells from human primary teeth enables the easy application of cells in laboratorial studies, reducing the cost and time for obtaining the samples, avoid the involvement of new subjects and allow a fast reproducibility of the researches.
\end{abstract}

\section{KEYWORDS}

Cell culture techniques; Tooth, deciduous; Pulp; Fibroblasts; Cryopreservation.

\section{RESUMO}

Objetivo: O objetivo deste estudo foi isolar células do tecido pulpar de dentes decíduos humanos, avaliar a capacidade de proliferação, caracterizá-las e normatizar as técnicas de cultivo e expansão celular destas para a criação de um banco de células. Material e métodos: Dentes decíduos sem cárie e com indicação ortodôntica de para extração foram utilizados como doadores de tecido para a pesquisa. As células foram extraídas de tecidos pulpares, isoladas e cultivadas em condições ideais até alcançarem confluência. Resultados: Após consecutivas passagens, as células cultivadas foram caracterizadas por meio de técnicas de imunofluorescência e congeladas entre a $2^{\mathrm{a}}$ e a $6^{\mathrm{a}}$ passagem, criando-se um biorrepositório de células da polpa de dentes decíduos humanos. Conclusão: A criação de bancos de células pulpares de dentes decíduos humanos permite uma aplicação mais ágil nas pesquisas laboratoriais, reduzindo o tempo e o custo da obtenção de novas amostras. Evita necessidade de triagem e obtenção de novos doadores de dentes e tecidos, e permite maior rapidez nas repetições de protocolos de pesquisas.

\section{PALAVRAS-CHAVE}

Técnicas de cultura de células; Dente decíduo; Polpa dentária; Fibroblastos; Criopreservação. 


\section{INTRODUCTION}

The development of cell cultures has microscopically normal cell events. Currently, this methodology is largely explored in researches on many knowledge areas because the obtained results are very close or equal to those observed in living organisms [12]. Moreover, laboratorial studies are reproducible, have excellent cost-benefit ratio, are pertinent and adequate to guide in vivo experiments [3-5].

In Dentistry, dental tissues for culture of primary cells as dentin, gingiva, and pulp can be obtained during routine procedures [6]. The primary cells exhibit a morphology identical to the tissues of origin, maintain the physiologic features, and can represent the natural conditions of an organism $[1,7]$.

Recent researches demonstrate a great potential of the pulp tissue from exfoliating primary teeth because this tissue is rich in undifferentiated mesenchymal cells, which raise great scientific interest to evaluate the bioactive potential and possible clinical applications [811]. The easy access to pulp tissue, obtained from a non-vital organ that is normally discarded after extraction, are very attractive in research. Notwithstanding, limitations in obtaining, culturing and controlling of the cell proliferation emphasize the search for new sources, techniques, and applications [7,12-13].

Different methodologies can be employed to establish the culture of primary cells from pulp tissue. As far as we are concerned, the literature lacks a methodology specific for primary tooth. The techniques of pulp cells culture used recently are adaptations from methodologies used for obtaining pulp cells from the permanent teeth $[6,12]$.

This study aimed to isolate the cells from the dental pulp tissue of human primary teeth, study the capacity of proliferation, characterize the cells and standardize the technique of culture and expansion to create a cell banking.

\section{MATERIAL AND METHODS}

This study was submitted and approved by the Institutional Review Board regarding the ethical aspects (CAAE 49806215.6.0000.5417). The children referred to the Pediatric Dentistry clinics for extraction of sound teeth due to orthodontic reasons were selected as potential donors for collecting the pulp tissue. Inclusion criteria were children of both genders, aged from 5 to 9 years, with good general health. The exclusion criteria comprised teeth with caries lesions and children taking any type of medicines.

After extraction, the teeth were placed into falcon tubes containing Dulbecco's modified Eagle's medium (DMEM) (Gibco, Thermo Fisher Scientific in Waltham, MA, USA) supplemented with 20\% Fetal Bovine Serum (FBS) (Gibco, Thermo Fisher Scientific in Waltham, MA, USA). The pulp tissue was extracted through the apical foramen with the aid of sterile curettes and endodontic files. The collected pulp tissue was placed into a Petri plate $(100 \mathrm{~mm}$ in diameter $\mathrm{x} 10 \mathrm{~mm}$ height), cut at small pieces with the aid of $15 \mathrm{c}$ scalpel blade (Figure 1A), and then, immersed in the supplemented medium containing DMEM 20\% FBS supplemented with $600 \mu \mathrm{L}$ of penicillin (Gibco, Thermo Fisher Scientific in Waltham, MA, USA), $300 \mu \mathrm{L}$ of gentamicin (Gibco, Thermo Fisher Scientific in Waltham, MA, USA), and $100 \mu \mathrm{L}$ of amphotericin B (Gibco, Thermo Fisher Scientific in Waltham, MA, USA) (Figure1B, 1C and $1 \mathrm{D}$ ), and incubated at $37 \mathrm{oC}$ and $5 \% \mathrm{CO}_{2}$ for 40 minutes (Figure 1E). Elapsed that period, all content of the plate was collected and dispensed into a falcon tube, centrifuged at $1200 \mathrm{rpm}$ for 5 minutes at 200C (Figure $1 \mathrm{~F}, 1 \mathrm{G}$ and $1 \mathrm{H}$ ). The cell pellet was resuspended in new culture medium (DMEM 20\% FBS), and stored in $25 \mathrm{~cm}^{2}$ cell culture flasks incubated at $37 \mathrm{oC}$ and $5 \%$ $\mathrm{CO}_{2}$ (Figure 1I and 1J). 


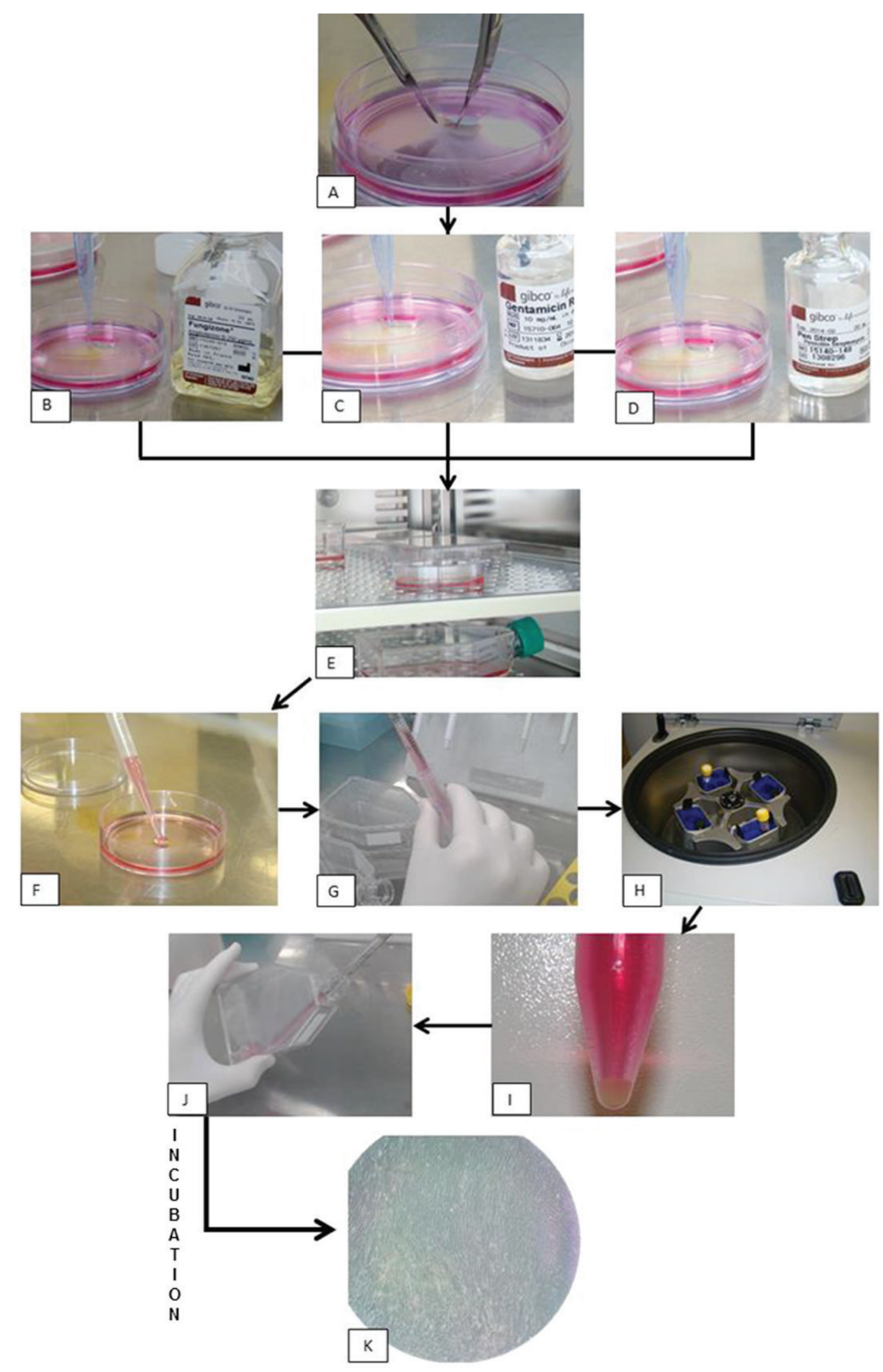

Figure 1 - Flowchart of the cell culture and isolation technique. 
The cell cultures were maintained with periodic changes of the culture medium (DMEM 20\% FBS) at every 48 hours until the cells reached confluence (Figure $1 \mathrm{~K}$ ), defining the passage zero (P0). Next, the cells were trypsinized, centrifuged, the pellet resuspended and transferred to $75 \mathrm{~cm}^{2}$ culture flasks. After confluence, the procedure was repeated to obtain the subsequent passages.

The isolated pulp cells were characterized as fibroblasts by immunofluorescence technique. The cells were marked with primary monoclonal antibody and anti-human fibroblast surface protein (Anti-FSP) (ABCAM, Cambridge, United Kingdom) at final concentration of $2 \mu \mathrm{g} / \mathrm{mL}$. Pulp cells from the $5^{\text {th }}$ passage were seeded at $10^{4}$ cells/well on 8-well chamber slide, left overnight to adhere on the well. Then, the cells were fixed in 4\% paraformaldehyde for 15 minutes and incubated with PBS supplemented with $3 \%$ bovine serum albumin for 30 minutes at environment temperature. After that, the cells were marked with the primary antibody (1:1000), left overnight; followed by the secondary antibody (1:500) (ABCAM, Cambridge, United Kingdom). The slides were prepared for the analysis through laser confocal microscopy (Leica TCS SPE, Mannheim, Germany).

\section{RESULTS}

The pulp tissue obtained from the extracted primary teeth allowed the primary cell culture. After 72 hours, the fragments of pulp tissue adhered on the flask surface (Figure 2A). At seven days of cell culture, the pulp cells started loosening (Figure 2B) and continued that way at 14 days (Figure 2C). After 21 days, the cell confluence was reached and the microscopic analysis revealed the normal morphology of the cells compatible with fibroblasts (Figure 2D). During all this study period, neither the medium nor the cell culture showed contamination. Also, marked cell death was not present.

The microscopic analysis of the slides marked by the immunofluorescence reaction with the antibody specific for fibroblast demonstrated positive immunostaining. The immunofluorescent staining of the selected antibody revealed the cell nuclei (Figure 3A) and cytoplasm (Figure 3B) with different colors, evidencing the cell morphology of fibroblasts (Figure 3C).

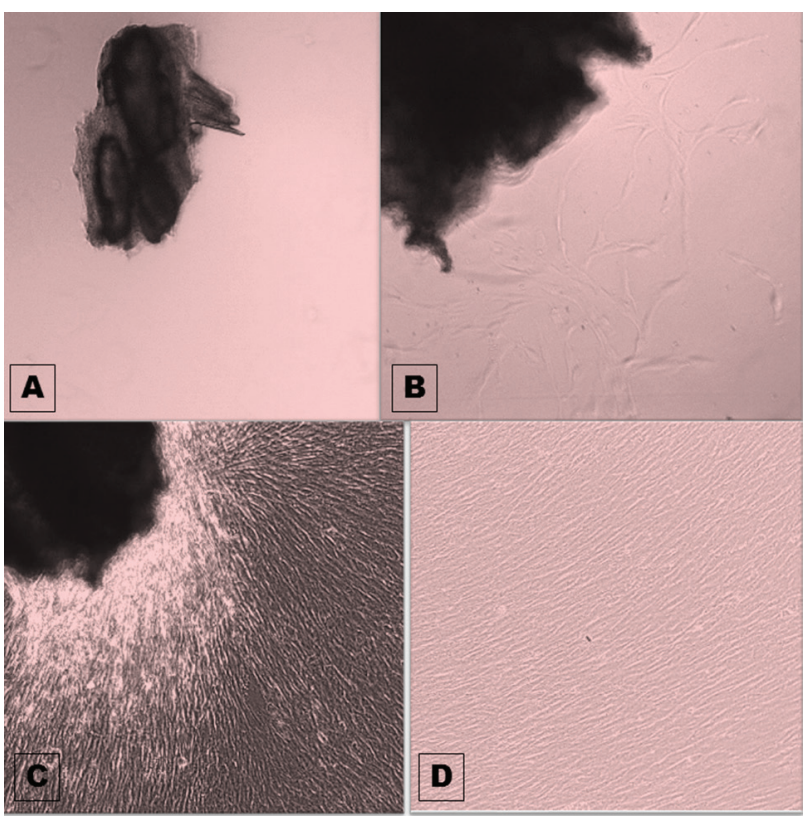

Figure 2 - (A) Fragment of pulp tissue at initial stage, (B) fragment of pulp tissue starting the cell loosening at 7 days, $(\mathrm{C})$ fragment of pulp tissue at advanced stage of cell proliferation at 14 days and (D) cell confluence after 21 days.

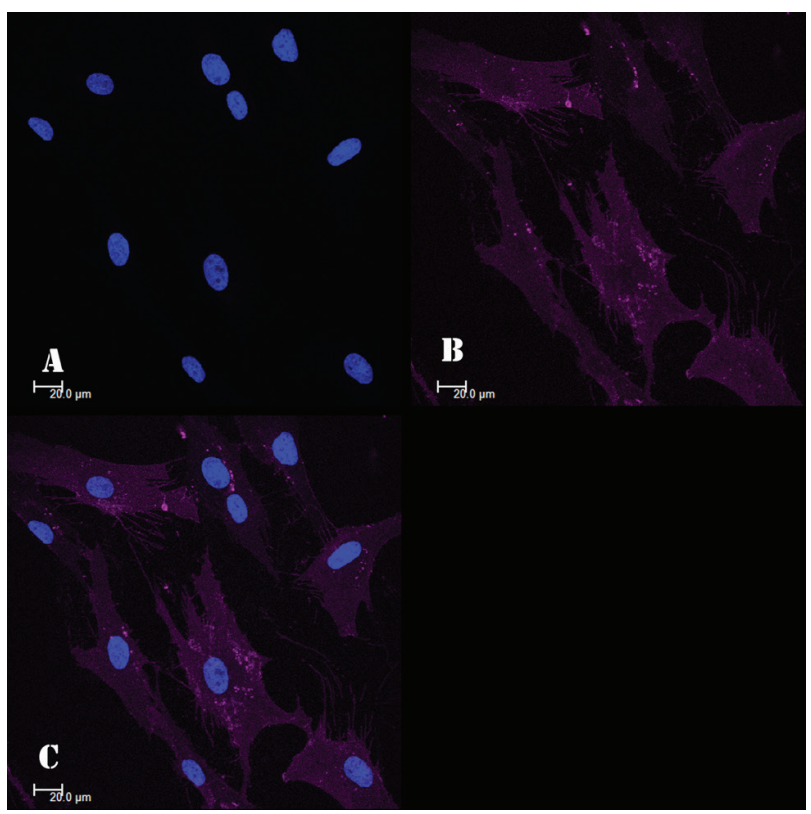

Figure 3 - (A) Morphology of the nuclei stained by immunofluorescence, (B) morphology of the cell membrane and cytoplasm stained by immunofluorescence, (C) characterization of the fibroblast immunostained by the specific immunofluorescent antibody. 


\section{DISCUSSION}

Researches on Dentistry field has investigated the potential of cell culture and tissue engineering, so this methodology can be used for investigating material's cytotoxicity, cell viability, and proliferation after different stimuli, guiding further clinical trials with lower cost, shorter time and small number of individuals [2,4-5,14-15]. However, the literature reports lack of standard techniques to obtain the cells from specific tissues [2,14]. Thus, it is important to investigate and standardize the cell culture techniques for different tissue types by characterizing the cells, using specific reagents, and correct storing the cells for further studies [14,16-18].

Currently, the cell culture technique has been used frequently in dental researches [4$5,15]$. The creation of cell banks either in study centers or for commercial purposes, resulted in great advances in the standardization of the technique for obtaining, culturing, and expanding many cell types, aiming at mutual collaboration between researchers and companies to achieve common guidelines on techniques and laboratorial supplies [17,19].

The guidelines on primary culture from tissue explants, mainly pulp and gingival tissue, have been the technique most adopted in dental researches [2,5-6]. The pulp tissue of primary teeth has some advantages, such as the cell pluripotency and explants easily obtained from the teeth extracted in pediatric dentistry clinics $[12-13,17]$. The studies of SIPERT et al. [5] and TORIUMI et al. [6] evidenced the need for standardizing the techniques of cell culture from the selection of the donor teeth or areas for obtaining the tissue explants to avoid culture contamination and accelerate the expansion of the cultured cells.

After obtaining the cells from primary culture, especially those from the pulp tissue of primary teeth, the characterization (i.e. determination of the cell type) is mandatory. For that purpose, many techniques may be employed: PCR, immunophenotyping, and fluorescence. The immunofluorescence through specific antigen-antibody systems is the most used technique at many research centers to determine cell types [2,12,17,20-21].

Although some authors stated that the pulp tissue explant is an atraumatic procedure relatively easy to obtain, the creation of cell banks is a viable option allowing the study of specific lineages, characterization and expansion through standard culture techniques, reducing the waste of laboratorial supplies, and eliminating the clinical step to obtaining those explants $[17,19,22]$.

Considering these advantages and the increasing use of cell cultures in researches and medical therapies, cell banks have gained space and importance. Accordingly, cell banking can be supported by companies aiming at the correct storage and manufacturing of the cells for further commercialization of the lineages. Cell banking contributes to obtaining different cell lineages and directly collaborates with the standardization of the specific techniques and supplies to be used and optimizes laboratorial studies with cell culture [2,23-24].

\section{CONCLUSION}

The creation of cell banking using dental pulp cells from human primary teeth enables the easy application of cells in laboratorial studies, reducing the cost and time for obtaining the samples, avoid the involvement of new subjects and allow a fast reproducibility of the researches.

\section{FUNDING}

This study received financial support from the Sao Paulo Research Foundation (FAPESP) (grants \#2013/18886-5). 


\section{REFERENCES}

1. Avinash K, Malaippan S, Dooraiswamy JN. Methods of Isolation and Characterization of Stem Cells from Different Regions of Oral Cavity Using Markers: A Systematic Review. Int J Stem Cells. 2017 May 30;10(1):12-20. doi: 10.15283/ijsc17010.

2. Ducret M, Fabre H, Farges JC, Degoul O, Atzeni G, McGuckin C, et al. Production of human dental pulp cells with a Medicinal manufacturing approach. J Endod. 2015 Sep;41(9):1492-9. doi: 10.1016/j.joen.2015.05.017. Epub 2015 Jul 17.

3. Koulaouzidou EA, Economides N, Beltes P, Geromichalos G, Papazisis K. In vitro evaluation of the cytotoxicity odProRoot MTA and MTA Angelus. J Oral Sci. 2008 Dec;50(4):397-402.

4. Morandini ACF, Souza PPC, Ramos-Junior ES, Brozoski DT, Sipert CR, Costa CAS, Santos CF. Tool-like receptor 2 knockdown modulates interleukin (IL)-6 and IL-8 but not stromal derived factor-1 (SDF-1/CXCL 12) in human periodontal ligament and gingival fibroblast. J Periodontol. $2013 \mathrm{Apr} ; 84(4): 535-44$. doi: 10.1902/jop.2012.120177. Epub 2012 Jun 9.

5. Sipert CR, Morandini ACF, Modena KCS, Dionísio TJ, Machado MAAM, Oliveira SHP, et al. CCL3 and CXCL12 production in vitro by dental pulp fibroblast from permanente and deciduous teeth stimulated by Porphyromonas gingivalis LPS. J Appl Oral Sci. 2013 Mar-Apr;21(2):99-105. doi: 10.1590/1678-7757201300004.

6. Toriumi T, Takayama N, Murakami M, Sato M, Yuguchi M, Yamazaki $\mathrm{Y}$, et al. Characterization of mesenchymal progenitor cells in the crown and root pulp of primary teeth. Biomed Res. 2015;36(1):31-45. doi: 10.2220/biomedres.36.31.

7. Zhang N, Chen B, Wang W, Chen C, Kang J, Deng SQ, et al. Isolation, characterization and multi-lineage differentiation of stem cells from human exfoliated deciduous teeth. Mol Med Rep. 2016 Jul;14(1):95-102. doi: 10.3892/mmr.2016.5214. Epub 2016 May 5.

8. Telles PD, Machado MAAM, Sakai VT, Nor JE. Pulp tissue from primary teeth: new source of stem cells. J Appl Oral Sci. 2011 MayJun;19(3):189-94.

9. Chatzistavrou X, Papagerakis S, Ma PX, Papagerakis P. Innovative approaches to regenerate enamel and dentin. Int J Dent. 2012;2012:856470. doi: 10.1155/2012/856470. Epub 2012 May 14.

10. Sujesh M, Rangarajan V, Ravi Kumar C, Sunil Kumar G. Stem cell mediated tooth regeneration: new vistas in dentistry. J Indian Prosthodont Soc. 2012 Mar;12(1):1-7. doi: 10.1007/s13191-011-0110-9. Epub 2011 Nov 4.

11. Rizk A, Rabie BM. Electroporation for transfection and differentiation of dental pulp stem cells. Biores Open Access. 2013 Apr;2(2):155-62. doi: 10.1089/biores.2012.0273.

12. Kerkis I, Caplan Al. Stem Cell in Dental Pulp of deciduous teeth Tissue Eng Part B Rev. 2012 Apr;18(2):129-38. doi: 10.1089/ten. TEB.2011.0327. Epub 2011 Dec 28.

13. Karbalaie K, Tanhaei S, Rabiei F, Kiani-Esfahani A, Masoudi N. S, Nasr-Esfahani H, et al. Stem Cells from human exfoliated deciduous tooth exhibit stromal-derived inducing activity and lead to generation of neural crest cells from human enbryonic stem cells. Cell J. 2015 Spring;17(1):37-48. Epub 2015 Apr 8.

14. Ferreira MPP, Ferrari RAM, Gravalos ED, Martins MD, Bussadori SK, Gonzalez DA, Fernandes KP. Effect of low energy galliumaluminum-arsenide and aluminium gallium indium phosphide laser irradiation on the viability of $\mathrm{C} 2 \mathrm{C} 12$ myoblasts in a muscle injury model. Photomed Laser Surg. 2009 Dec;27(6):901-6. doi: 10.1089/ pho.2008.2427.

15. Damante CA, De Micheli G, Miyagi SP, Feist IS, Marques MM. Effect of laser phototherapy on the release of fibroblast growth factors by human gingival fibroblasts. Lasers Med Sci. 2009 Nov;24(6):88591. doi: 10.1007/s10103-008-0582-y. Epub 2008 Jul 4.

16. Sloan AJ, Shelton RM, Hann AC, Moxham BJ, Smith AJ. An in vitro approach for the study of dentinogenesis by organ culture of the dentine-pulp complex from rat incisor teeth. Arch Oral Biol. 1998 Jun;43(6):421-30.

17. Arora V, Arora P, Munshi AK. Banking stem cells from human exfoliated deciduous teeth (SHED): saving for the future. J Clin Pediatr Dent. 2009 Summer;33(4):289-94.

18. Kim JH, Jeon M, Song JS, Lee JH, Choi BJ, Jung HS, et al. Distinctive genetic activity pattern of the human dental pulp between deciduous and permanent teeth. PLoS One. $2014 \mathrm{Jul}$ 21;9(7):e102893. doi: 10.1371/journal.pone.0102893. eCollection 2014.

19. Rai B. Stem Cells from human exfoliated deciduous teeth and SHED Bank: A Mini View. The Internet Journal of Bioengineering. 2006;2(2):1-2.

20. Takeda T, Tezuka Y, Horiuchi M, Hosono K, Lida K, Hatakeyama D, et al. Characterization of dental pulp stem cells of human tooth germs. J Dent Res. 2008 Jul;87(7):676-81.

21. Halfon S, Abramov N, Grinblat B, Ginis I. Markers distinguishing mesenchymal stem cells from fibroblasts are downregulated with passaging. Stem Cells Dev. 2011 Jan;20(1):53-66. doi: 10.1089/ scd.2010.0040. Epub 2010 0ct 26.

22. Perry BC, Zhou D, Wu X, Yang FC, Byers MA, Chu TM, Hockema JJ, Woods EJ, Goebel WS. Collection, cryopreservation, and characterization of human dental pulp-derived mesenchymal stem cells for banking and clinical use. Tissue Eng Part C Methods. 2008 Jun;14(2):149-56. doi: 10.1089/ten.tec.2008.0031.

23. Sensebé L, Bourin P, Tarte K. Good manufacturing practices production of mesenchymal stem/stromal cells. Hum Gene Ther. 2011 Jan;22(1):19-26. doi: 10.1089/hum.2010.197. Epub 2010 Dec 19.

24. Sensebé L, Gadelorge M, Fleury-Cappellesso S. Production of mesenchymal stromal/stem cells according to good manufacturing practices: a review. Stem Cell Res Ther. 2013 Jun 7:4(3):66. doi: 10.1186/scrt217.

\section{Thais Marchini Oliveira (Corresponding address)}

Bauru School of Dentistry, University of São Paulo

Alameda Dr. Octávio Pinheiro Brisolla, 9-75

Bauru, São Paulo, 17012-901- Brazil

Date submitted: 2017 Aug 04

E-mail: marchini@usp.br Accept submission: 2017 Sep 20 